\title{
Rectal mucosal plasma cells in inflammatory bowel disease
}

\author{
B B SCOTT, ANNE GOODALL, P STEPHENSON, AND D JENKINS
}

From the Departments of Medicine and Pathology, Lincoln County Hospital, Lincoln

SUMMARY To achieve optimum staining and reproducible counts of plasma cells in paraffin embedded tissue with the immunoperoxidase technique we have found it essential to obtain a plateau count by titration of antisera for each specimen. This modification was used to study $\operatorname{IgA}$, IgM, IgE, and IgG plasma cells in rectal biopsies from 20 controls, 20 patients with ulcerative proctocolitis, 20 with Crohn's colitis, 20 with non-specific proctitis, 15 with bacterial colitis, and seven with Crohn's disease but no apparent large bowel involvement. Counts were correlated with the characteristic histological features of inflammatory bowel disease. In controls the ratio of the mean counts for IgA, IgM, IgE, and IgG plasma cells was 8:3:3:1. All types of plasma cells were very significantly increased in the patients with ulcerative proctocolitis, Crohn's colitis, and non-specific proctitis and counts correlated with the severity of inflammation. There was no significant difference between the counts in these three groups. All counts tended to be higher in bacterial colitis than in controls, the difference being significant for $\operatorname{IgA}$ and IgE. When matched for severity of inflammation there was no significant difference between the counts in bacterial colitis and inflammatory bowel disease. The counts in patients with Crohn's disease but no large bowel involvement were not significantly different from controls. These results suggest that changes in plasma cell counts in inflammatory bowel disease are a non-specific reponse to mucosal damage, possibly by a luminal irritant, and do not differentiate the type of inflammatory bowel disease.

Ulcerative proctocolitis and Crohn's colitis are common diseases of unknown aetiology in which imunological mechanisms play a part. The differentiation of these two conditions, although often very difficult, is of practical importance in relation to both medical and surgical treatment. Non-specific proctitis is usually considered a mild variant of ulcerative proctocolitis but there are a number of differences, ${ }^{1}$ which suggest they might be separate conditions. Changes in the total and differential rectal mucosal plasma cell counts have been reported in all three conditions. ${ }^{2-9}$ The different studies have given strikingly conflicting results, however, and there is even great variation between the results in control groups. ${ }^{3} 5-810-12$ There are probably several reasons for the conflicting results. One is the small numbers of patients studied - for controls the average number is nine, for ulcerative

Address for correspondence: Dr B B Scott, Lincoln County Hospital, Sewell Road, Lincoln LN2 5QY.

Received for publication 27 August 1982 proctocolitis 10 , for non-specific proctitis 15 , and for Crohn's disease 11. Another, and probably most important reason is differences in technique. The majority of studies have used immunofluorescence. This is unsatisfactory for accurate counting of plasma cells as it is difficult to distinguish extracellular from intracellular staining, and it is difficult to recognise the type of cells in which positive staining is found. Furthermore, it is not possible to assess other histological features of inflammatory bowel disease. Immunoperoxidase staining is much more satisfactory as the morphology of the cells can be well seen and miscounting of plasma cells is less likely. Furthermore, as paraffin sections are used, routine histology can be done as well. We have found in preliminary studies, however, that immunoperoxidase staining is very dependent upon the concentration of antisera and no single concentration gives optimum and reproducible staining for each specimen. It is therefore necessary to individually titrate each antiserum with each specimen so that counting is done at a plateau level 
of staining. Another reason for conflicting results may be the failure to match for the degree of inflammation.

In view of these considerations we felt it important to reinvestigate plasma cell counts in inflammatory bowel disease using larger numbers of patients and controls, an immunoperoxidase technique in which each specimen is individually titrated with antiserum, and relating the results to the severity of inflammation. In addition, we thought it important to look at patients with a known cause for colitis - that is, patients with a bacterial colitis - and also to look at patients with Crohn's disease but no apparent large bowel involvement especially as another study of Crohn's disease has shown changes in total plasma cells in apparently uninvolved mucosa. ${ }^{13}$

\section{Methods}

\section{PATIENTS}

Control group Twenty patients with diarrhoea, eight men, 12 women; mean age 38 years, who after investigation were considered to have the irritable bowel syndrome and had no sign of organic gastrointestinal disease.

Ulcerative proctocolitis group Twenty patients with diarrhoea, nine men, 11 women; mean age 44 years, all of whom had sigmoidoscopic appearances typical of ulcerative proctocolitis and a barium enema showing colonic involvement above the sigmoid colon. In 15 patients disease was apparently confined to the left side of the colon and in five it extended into the right side. The mean duration of disease was four years. Sixteen were taking sulphasalazine and none was taking steroids at the time of biopsy.

Non-specific proctitis group Twenty patients with diarrhoea, 10 men, 10 women; mean age 38 years, all of whom had typical sigmoidoscopic appearances of proctitis. There was either an upper limit of disease seen at rigid sigmoidoscopy or no evidence of colonic disease on barium enema. The mean duration of disease was four years. Fourteen were taking sulphasalazine and none was taking steroids at the time of biopsy.

Crohn's colitis group Twenty patients with diarrhoea, 13 men and seven women; mean age 40 years. The diagnosis of Crohn's disease was based mainly upon the presence of radiological evidence of small bowel disease in nine patients, discontinuous disease in one patient, typical endoscopic appearances in three patients, examination of resected colon in four patients, and typical conventional histology on rectal biopsy in three patients. The mean duration of disease was four years. Eleven were taking sulphasalazine and none was taking steroids at the time of biopsy.

Bacterial colitis group Fifteen patients with an acute diarrhoeal illness, seven men, eight women; mean age 45 years. In eight the diarrhoea was closely associated with antibiotic therapy and four of these had a positive stool culture for Clostridium difficile. Three had Salmonellosis, three had a campylobacter infection, and one had yersinia enterocolitis.

Small bowel Crohn's group Eight patients, five men, three women; mean age 36 years, with radiological evidence of small bowel Crohn's disease and no evidence of disease of the colon or rectum on sigmoidoscopy and barium enema. None was taking sulphasalazine or steroids at the time of biopsy.

\section{STAINING TECHNIQUES}

Rectal biopsies were taken during the course of routine management using Brock's biopsy forceps. They were immediately placed in formalin and the fixed specimens were embedded into paraplast. Tissue sections were cut at $1 \mu$ thickness perpendicular to the luminal surface, mounted on glass slides and dried overnight at $37^{\circ} \mathrm{C}$. Sections were stained for IgA, IgM, IgE, and IgG by the PAP immunoperoxidase technique ${ }^{14}$ after initial trypsinisation, ${ }^{15}$ and counterstained with Harris haematoxylin for the morphometric study. Rabbit anti-human immunoglobulin heavy chain antisera, together with swine anti-rabbit antiserum, and peroxidase-rabbit antiperoxidase complex were obtained from Dakopatts. Specificity of the primary antisera was confirmed by immunoelectrophoresis and by testing against human monoclonal myeloma cases. Particular care was taken to standardise the anti-IgE antiserum using positive and negative substrates in view of the reported high incidence of cross reactivity with $\operatorname{IgA} .^{16}$ We used a single batch of anti-IgE antiserum for the whole study and no cross reactivity was detected with this batch on control sections. Titration of primary antisera in the range 1:50 to $1: 32000$ showed that at high dilutions the count of immunoglobulin containing cells fell with decreasing titre. In the intermediate range consistent cell counts could be shown graphically to lie on a plateau. At high concentration non-specific staining made identification of cellular imunoglobulin very inaccurate. For these reasons cell counts were made within the plateau range. This was found to vary from case to case and the titration was therefore performed for each case to obtain plateau count.

MEASUREMENTS

Measurements and cell counts on the immunoper- 
oxidase stained sections were carried out using a MOPPET image analyser. An image of the stained sections was projected at standard magnification on to the digitising tablet by a Leitz Neopromar projection microscope. The MOP stylus was fitted with a ball point pen to provide a permanent record of the field examined. Four contiguous, nonoverlapping fields were examined on each section. A field was defined as the area between the mucosal surface and muscularis mucosae bounded by two lines perpendicular to the mucosal surface and muscularis mucosae. The following three measurements were made on each field: (1) mean mucosal length - the mean of the length of the muscularis mucosae and the length of the mucosal surface which gives an accurate measure of the true mucosal length, allowing for specimen curvature during preparation $;{ }^{17}(2)$ area of lamina propria; and (3) immunoglobulin-containing cell counts. A micrometer slide was used to convert area and length measurements on the projected image into absolute measurement. For each section cell counts were expressed as cells $/ \mathrm{mm}$ mean mucosal length and as cells $/ \mathrm{mm}^{2}$ lamina propria area. All measurements and processing were performed blind on randomised specimens to minimise experimental and observer bias. Haematoxylin and eosin stained sections from each specimen in all groups with rectal disease were graded histopathologically on a score $0,1,2,3$ for each of the 10 following pathological features ulceration, epithelial polymorphonuclear cells, crypt abscesses, lamina propria polymorphonuclear cells, lamina propria chronic inflammatory cells, granulomata, submucosal involvement, lymphoid follicles, patchiness, and architectural distortion.

\section{STATISTICAL METHODS}

Immunoglobulin-containing cell counts in each disease group were compared with those of the control group and each other group using the Student's $t$ test with Bessel's correction for small samples and, for IgG and IgM, log transformation. Linear regression analysis of cell numbers per field against both area and length of that field was performed, and for counts of each immunoglobulin-containing cell type against each other in each of the disease groups and the control group. Linear regression analysis was also performed for the counts of each immunoglobulin-containing cell type against each of the 10 histological features in the pooled diseases groups.

\section{Results}

The results were similar whether the counts were expressed as cells per $\mathrm{mm}^{2}$ of lamina propria or per mm mucosal length. Linear regression analysis of cell numbers in each field against both area and length of that field, however, suggested that cells per $\mathrm{mm}$ mucosal length is the more representative expression. Therefore, for convenience, only the results expressed as cells per mm mucosal length will be presented. The plasma cell counts are shown in Figs $1-4$. The ratio of the mean counts for IgA, IgM, IgE, and IgG plasma cells in the control group was 8:3:3:1 respectively and the upper limits of the normal ranges (mean $+2 \mathrm{SD}$ of the control group) were $398,188,170$, and 143 per $\mathrm{mm}$ respectively. All types of plasma cells were very significantly increased compared with controls in the ulcerative proctocolitis group, the non-specific proctitis group, and the Crohn's colitis group $(p<0.001$ for all types of plasma cells except IgM in the proctitis group where $p<0.005$ ) and there was no significant difference between these groups. There was no correlation between the use of sulphasalazine and the plasma cell counts. There was a positive correlation between all plasma cell counts, especially IgG, and the overall severity of inflam-

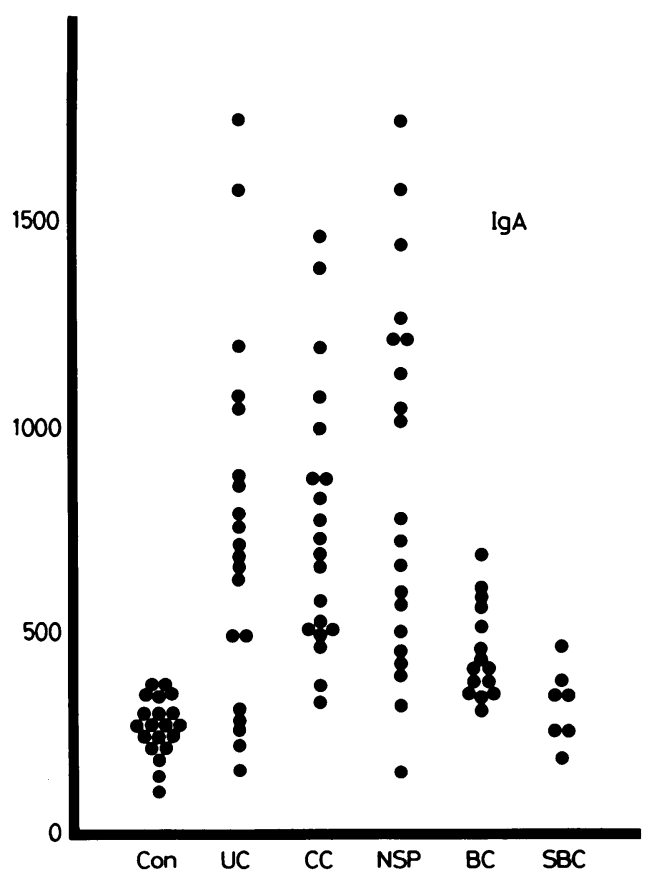

Fig. 1 IgA plasma cell counts per mm mean mucosal length in different groups. Con = controls; $U C=$ ulcerative proctocolitis; $C C=$ Crohn's colitis; $N S P=$ non-specific proctitis; $B C=$ bacterial colitis; $S B C=$ small bowel Crohn's disease. 


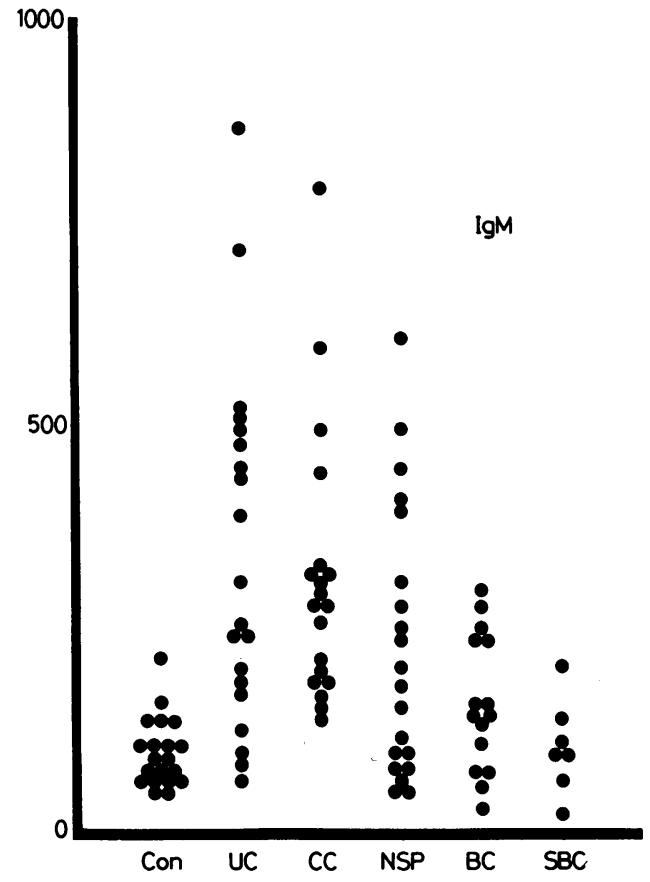

Fig. 2 IgM plasma cell counts per mm mean mucosal length in different groups. Con = controls;

$U C=$ ulcerative proctocolitis; $C C=$ Crohn's colitis; $N S P=$ non-specific proctitis; $B C=$ bacterial colitis; $S B C=$ small bowel Crohn's disease.

mation. There were also correlations between individual histological features and the plasma cell counts as shown in the Table. The patients in the ulcerative proctocolitis and Crohn's colitis groups were well matched for severity of inflammation. The counts of all types of plasma cells tended to be higher in the bacterial colitis group compared with controls but this was significant only for IgA

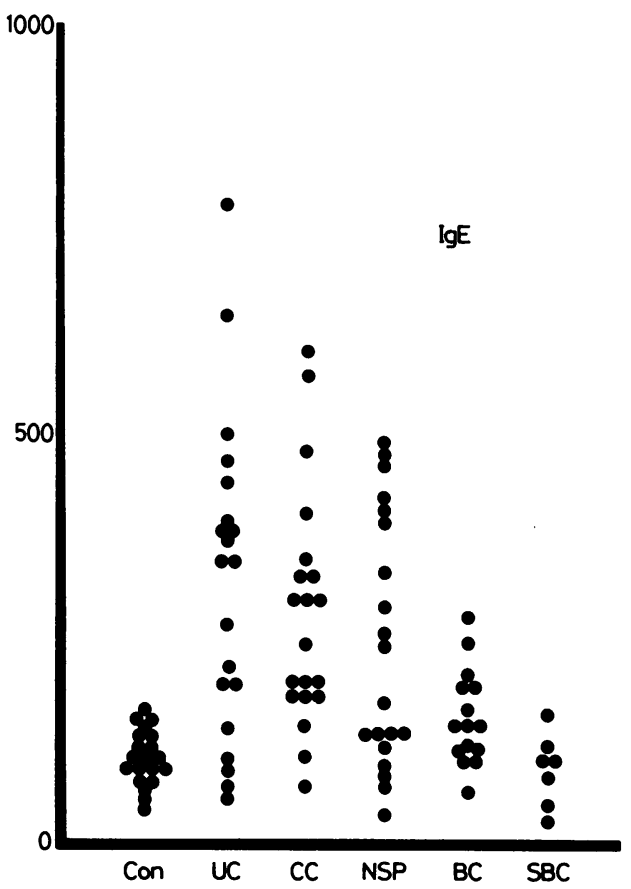

Fig. 3 IgE plasma cell counts per mm mean mucosal length in different groups. Con = controls;

$U C=$ ulcerative proctocolitis; $C C=$ Crohn's colitis; $N S P=$ non-specific proctitis; $B C=$ bacterial colitis; $S B C=$ small bowel Crohn's disease.

$(p<0.001)$ and $\operatorname{IgE}(p<0.005)$. The severity of inflammation was less in this group than in those with inflammatory bowel disease and when compared with biopsies from patients with inflammatory bowel disease having a similar degree of inflammation there was no significant difference. The plasma cell counts in the small bowel Crohn's group were not significantly different from controls.

Table Significance of correlations between individual histological features and the counts of the different types of plasma cells in the 75 patients with inflammatory bowel disease and bacterial colitis

\begin{tabular}{|c|c|c|c|c|c|c|c|c|c|c|}
\hline $\begin{array}{l}\text { Plasma } \\
\text { cell } \\
\text { type }\end{array}$ & $\begin{array}{l}\text { Ulcera- } \\
\text { tion }\end{array}$ & $\begin{array}{l}\text { Epithelial } \\
\text { poly- } \\
\text { morphs }\end{array}$ & $\begin{array}{l}\text { Crypt } \\
\text { abscesses }\end{array}$ & $\begin{array}{l}\text { Lamina } \\
\text { propria } \\
\text { poly- } \\
\text { morphs }\end{array}$ & $\begin{array}{l}\text { Lamina } \\
\text { propria } \\
\text { CICs }\end{array}$ & $\begin{array}{l}\text { Granulo- } \\
\text { mata }\end{array}$ & $\begin{array}{l}\text { Sub- } \\
\text { mucosal } \\
\text { involve- } \\
\text { ment }\end{array}$ & $\begin{array}{l}\text { Lymphoid } \\
\text { follicles }\end{array}$ & Patchiness & $\begin{array}{l}\text { Archi- } \\
\text { tectural } \\
\text { distortion }\end{array}$ \\
\hline $\begin{array}{l}\text { IgA } \\
\text { IgE } \\
\text { IgM } \\
\text { IgG }\end{array}$ & $\begin{array}{l}\text { NS } \\
p<0.001 \\
N S \\
p<0.001\end{array}$ & $\begin{array}{l}\mathrm{p}<0.001 \\
\mathrm{NS} \\
\mathrm{NS} \\
\mathrm{p}<0.001\end{array}$ & $\begin{array}{l}p<0.001 \\
p<0.001 \\
N S \\
p<0.005\end{array}$ & $\begin{array}{l}p<0.001 \\
p<0.001 \\
N S \\
p<0.001\end{array}$ & $\begin{array}{l}p<0.001 \\
p<0.001 \\
p<0.001 \\
p<0.001\end{array}$ & $\begin{array}{l}\text { NS } \\
\text { NS } \\
\text { NS } \\
\text { NS }\end{array}$ & $\begin{array}{l}\text { NS } \\
\text { NS } \\
\text { NS } \\
p<0.001\end{array}$ & $\begin{array}{l}p<0.01 \\
N S \\
p<0.005 \\
p<0.001\end{array}$ & $\begin{array}{l}\text { NS } \\
\text { NS } \\
\text { NS } \\
\text { NS }\end{array}$ & $\begin{array}{l}\text { NS } \\
\text { NS } \\
\text { NS } \\
p<0 \cdot 001\end{array}$ \\
\hline
\end{tabular}

CICs = chronic inflammatory cells; $\mathbf{N S}=$ not significant. 


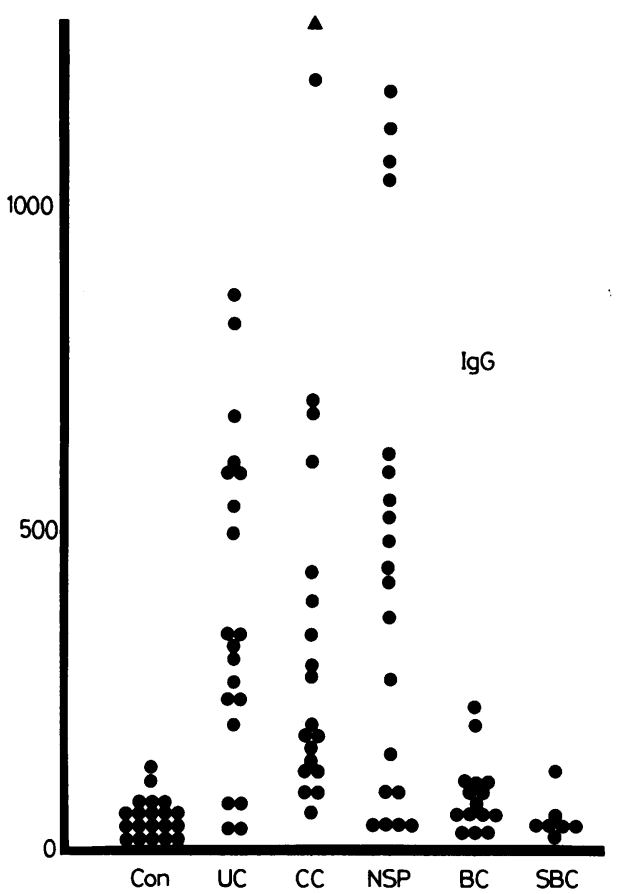

Fig. 4 IgG plasma cell counts per mm mean mucosal length in different groups. Con = controls;

$U C=$ ulcerative proctocolitis; $C C=$ Crohn's colitis;

$N S P=$ non-specific proctitis; $B C=$ bacterial colitis;

$S B C=$ small bowel Crohn's disease $; \boldsymbol{\Delta}=$ one patient with a count of 1973.

\section{Discussion}

These result show that there is a significant increase in all types of plasma cells in the diseased rectum of patients with inflammatory bowel disease and the increase is proportional to the severity of inflammation. They do not suggest any difference between ulcerative proctocolitis and Crohn's colitis nor do they provide a means of distinguishing Crohn's colitis from ulcerative proctocolitis as has recently been suggested. ${ }^{9}$ We have shown no difference between patients with ulcerative proctocolitis and those with non-specific proctitis. In particular we find no difference in the IgE plasma cell counts and therefore provide no support for the suggestion that IgE-mediated mechanisms are particularly important in proctitis. ${ }^{89}$ Nor do we find evidence for changes in plasma cells in the apparently uninvolved bowel of patients with Crohn's disease. As the counts are related to the severity of inflammation and as similar increases are found in bacterial colitis it seems likely that the increase in plasma cell counts in inflammatory bowel disease is a non-specific response to mucosal damage, possibly by a luminal irritant, and do not differentiate the types of inflammatory bowel disease.

We thank the Trent Regional Health Authority Research Committee for generous financial support, and Professors I P M Dawson and M S Losowsky for advice.

\section{References}

1 Earnest DL. Nonspecific ulcerative proctitis. In: Sleisenger MH, Fordtran JS, eds. Gastrointestinal disease. Philadelphia: Saunders, 1978: 1868-9.

2 Gelzayd EA, Kraft SC, Fitch FW, Kirsner JB. Distribution of imunoglobulins in human rectal mucosa. II. Ulcerative colitis and abnormal mucosal control subjects. Gastroenterology 1968; 54: 341-7.

3 Ballard J, Shiner M. Evidence of cytotoxicity in ulcerative colitis from immuncfluorescent staining of the rectal mucosa. Lancet $1974 ; 1:$ 1014-7.

4 Skinner JM, Whitehead R. The plasma cells in inflammatory disease of the colon: a quantitative study. J Clin Pathol 1974; 27: 643-6.

5 Brandtzaeg P, Baklein K, Fausa O, Hoel PS. Immunohistochemical characterization of local immunoglobulin formation in ulcerative colitis. Gastroenterology 1974; 66: 1123-36.

6 Heatley RV, Rhodes J, Calcraft BJ, Whitehead RH, Fifield R, Newcombe RG. Immunoglobulin $\mathrm{E}$ in rectal mucosa of patients with proctitis. Lancet 1975; 2: 1010-2.

7 O'Donoghue DP, Kumar P. Rectal IgE cells in inflammatory bowel disease. Gut 1979; 20: 149-53.

8 Rosekrans PCM, Meijer CJLM, Van der Wal AM, Lindeman J. Allergic proctitis, a clinical and immunopathological entity. Gut 1980; 21: 1017-23.

9 Rosekrans PCM, Meijer CJLM, Van der Wal AM, Cornelisse $\mathrm{CJ}$, Lindeman $\mathrm{J}$. Immunoglobulin containing cells in inflammatory bowel disease of the colon: a morphometric and immunohistochemical study. Gut 1980; 21: 941-7.

10 Crabbe PA, Heremans JF. The distribution of immunoglobulin-containing cells along the human gastrointestinal tract. Gastroenterology 1966; 51: 30516.

11 Gelzayd EA, Kraft SC, Kirsner JB. Distribution of immunoglobulins in human rectal mucosa. I. Normal control subjects. Gastroenterology 1968; 54: 334-40.

12 Savilahti E. Immunoglobulin-containing cells in the intestinal mucosa and immunoglobulins in the intestinal juice in children. Clin Exp Immunol 1972; 11: 415-25.

13 Ferguson R, Allan RN, Cooke WT. A study of the cellular infiltrate of the proximal jejunal mucosa in 
ulcerative colitis and Crohn's disease. Gut 1975; 16: 205-8.

14 Taylor CR. Immunoperoxidase techniques. Arch Pathol Lab Med 1978; 102: 113-21.

15 Curran RC, Gregory J. The unmasking of antigens in paraffin sections by trypsin. Experentia 1977; 33: $1400-1$.
16 Piris J, Murdoch DL. Immunoglobulin E in ulcerative colitis and non-specific proctitis - studies with a monoclonal antibody. (Abstract.) Gut 1981; 22: A8756.

17 McKintyre RLC, Piris J. Quantification of human gastric $\mathbf{G}$ cell density in endoscopic biopsy specimens: effect of shape of specimen. J Clin Pathol 1980; 33: 513. 